Original Research Paper

\title{
Diseminasi Teknologi Pembuatan Abon yang Berbasis Daging Ayam Petelur Afkir
}

\author{
Bulkaini $^{1 *}$, B.R.D Wulandari ${ }^{2}$, Djoko Kisworo ${ }^{3}$, Sukirno $^{4}$, Wahid Yulianto ${ }^{5}$ \\ 1,2,3,4,5 Faculty of Animal Husbandry, University of Mataram Jalan Majapahit No.62 Mataram West Nusa \\ Tenggara.
}

DOI: https://doi.org/10.29303/jpmpi.v3i2.516

Sitasi:. Bulkaini., Wulandari, B. R. D., Kisworo. D., Sukirno., \& Yulianto, W. (2020). Diseminasi Teknologi Pembuatan Abon yang Berbasis Daging Ayam Petelur Afkir. Jurnal Pengabdian Magister Pendidikan IPA, 3(2)

\author{
Article history \\ Received: 25 Oktober \\ Revised: 15 Nopember \\ Accepted: 29 Nopember \\ *Corresponding Author: \\ Bulkaini, \\ Faculty of Animal Husbandry, \\ University of Mataram Jalan \\ Majapahit No.62 Mataram \\ West Nusa Tenggara. \\ Email: \\ b_kaini@yahoo.com
}

\begin{abstract}
Abstrak: Abon merupakan salah satu produk olahan yang sudah terkenal dimasyarakat dengan tingkat penerimaan yang tinggi. Bahan baku utama pembuatan abon adalah daging sapi dan berbagai jenis daging lainya misalnya daging ayam petelur afkir. Daging ayam petelur afkir tergolong daging yang alot, sehingga untuk meningkatkan keempukannya perlu dilakukan pengolahan menjadi bentuk lain misalnya diolah menjadi abon. Kegiatan pengabdian dilakukan di Desa Bajur Kecamatan Labuapi Lombok Barat dengan tujuan untuk meningkatkan pengetahuan dan keterampilan ibu-ibu PKK Desa Bajur dalam membuat abon daging serta menumbuhkan jiwa enterpreneur dalam usaha pembuatan abon. Tingkat pengetahuan dan keterampilan ibu-ibu PKK yang masih rendah serta belum terbentuknya jiwa enterpreneur yang dianggap sebagai permasalahan selama ini dapat diatasi melalui kegiatan pelatihan pembuatan abon dengan Metode action reseach, metode pendampingan dan diseminasi teknologi yang dilaksanakan secara persuasive. Kegiatan pengabdian ini menghasilkan suatu produk berupa abon yang berbasis daging ayam petelur afkir dengan kandungan nilai gizi yang telah memenuhi ketentuan SNI: kadar air 14,33\%, protein 20,34\%, lemak $28,98 \%$, dan abu $5,17 \%$ dengan nilai protein terlarut $0,11 \%$, sedangkan menurut SNI nilai gizi abon daging sapi dan daging jenis lainnya yaitu kadar air sebesar $7 \%$, protein $15 \%$, lemak $30 \%$, dan kadar abu sebesar $7 \%$. Secara keseluruhan hasil capaian dari kegiatan pengabdian kepada masyarakat adalah tingkat pengetahuan dan keterampilan ibu-ibu PKK dalam membuat abon meningkat sebesar $90 \%$.
\end{abstract}

Kata Kunci: Abon, Daging Ayam Afkir, Jiwa Enterpreneur

\section{Pendahuluan}

Abon adalah suatu jenis makanan kering berbentuk khas, dibuat dari daging, direbus, disayat-disayat, dibumbui, digoreng dan dipres. Abon merupakan daging kering yang telah disayat-sayat menjadi serat-serat yang halus dan umumnya dibuat dari daging sapi. Sebenarnya, semua jenis daging seperti daging ayam bahkan ikan dapat digunakan sebagai bahan baku abon. Semakin meningkatnya permintaan konsumen terhadap jumlah dan variasi rasa abon maka diperlukan penggunaan jenis bahan baku yang bervariasi. Tidak hanya itu, untuk memenuhi keinginan konsumen, kini abon dibuat dengan rasa yang bervariasi. Beberapa rasa abon yang ada dipasar yaitu manis, asin, dan pedas (Bulkaini, 2018).

Abon umumnya memiliki komposisi gizi yang cukup baik karena umumnya terbuat dari 
daging ditambah dengan beberapa jenis bumbu (Bulkaini et al.,2019). Pengolahan daging menjadi abon bertujuan untuk menambah keanekaragaman pangan, memperoleh pangan yang berkualitas tinggi, tahan selama penyimpanan, meningkatkan nilai tukar, dan meningkatkan daya guna bahan mentahnya. Abon sebagai salah satu bentuk olahan kering yang sudah dikenal masyarakat luas karena harganya cukup terjangkau dan lezat (Bulkaini et al, 2017).

Dalam usaha pembuatan abon, tidak hanya meggunakan daging yang berasal dari ternak daging sapi, kambing, domba, ayam yang masih berproduksi, tetapi bisa menggunakan daging yang bersumber dari ternak yang sudah afkir, misal ayam petelur afkir. Ayam petelur afkir adalah ayam betina petelur dengan produksi telur yang rendah sekitar 20 sampai $25 \%$ pada umur pemeliharaan sekitar 96 minggu atau 2 tahun (Yuwanto, 2004). Daging ayam petelur afkir memiliki tekstur yang kasar, alot. Tekstur merupakan ukuran ikatan-ikatan serabut otot yang dibatasi oleh septum- septum perimiseal jaringan ikat yang membagi otot secara longitudinal. Tekstur otot dibagi menjadi dua kategori yang tekstur kasar dengan ikatanikatan serabut yang besar dan tekstur halus. Tingkat kekasaran tekstur meningkat seiring bertambahnya umur (Soeparno, 2011). Daging ayam petelur afkir mengandung air 56\%, protein $25,4 \%$ sampai $31,5 \%$ dan lemak 1,3 sampai 7,3\%. Kandungan nutrisi daging petelur afkir tidak jauh berbeda dengan daging broiler, namun demikian ayam petelur afkir memiliki kelemahan yaitu dagingnya keras dan alot karena dipotong pada umur yang tua (Mountney dan Parkhurst, 1995). Dengan pertimbangan nilai gizi yang terkandung dalam daging ayam petelur afkir, maka dilakukan pelatihan pembuatan abon berbasis daging ayam petelur afkir melalui program pengabdian kepada masyarakat.

Kegiatan pengabdian kepada masyarakat bertujuan:1) Meningkatkan pengetahuan dan keterampilan Ibu-ibu PKK Desa Bajur
Kecamatan Labuapi Kabupaten Lombok Barat dalam membuat abon daging ayam petelur apkir dan 2) Menumbuhkan jiwa Enterpreneur Ibu-ibu PKK dalam usaha pembuatan abon daging ayam petelur apkir

\section{Metode}

2.1. Pihak yang terlibat dalam kegiatan pengabdian kepada masyarakat

Dalam kegiatan pengabdian kepada masyarakat melibatkan unsur-unsur dari pemerintahan desa yaitu Kadus dan Ketua RT, Desa Bajur Kecamatan Labuapi Kabupaten Lombok Barat dan Ibu-Ibu PKK desa setempat.

2.2. Metode dan tahapan pelaksanaan pengabdian kepada masyarakat.

a. Identifikasi kebutuhan masyarakat

Kegiatan yang dilakukan dalam identifikasi kebutuhan teknologi adalah melakukan wawancara dengan masyarakat calon peserta pelatihan. Hasil wawancara tersebut dicocokkan dengan data sekunder yang ada di Kantor Desa setempat yang terkait dengan data SDM.

b. Metode Perancangan dan pembuatan paket teknologi

Kegiatan perancangan dan pembuatan paket teknologi yang akan di diterapkan dilakukan dengan metode pendekatan PRA (Participatory Research Appraisal) yaitu dirancang secara bersama-sama antara pihak tim pelaksana dengan calon peserta yaitu paket teknologi pembuatan abon daging ayam petelur afkir yang higienis dan mendesain kemasan produk.

c. Penerapan teknologi kepada peserta

Metode penerapan teknologi kepada peserta pengabdian kepada masyarakat dilakukan dengan metode demonstrasi. Penerapan teknologi dilaksanakan secara persuasif yaitu: 1) praktik pembuatan pembuatan abon yang higienis dan 2) praktik pembuatan berbagai bentuk kemasan abon. Diagram alir pembuatan abon daging ayam petelur afkir disajikan pada Gambar 1. 


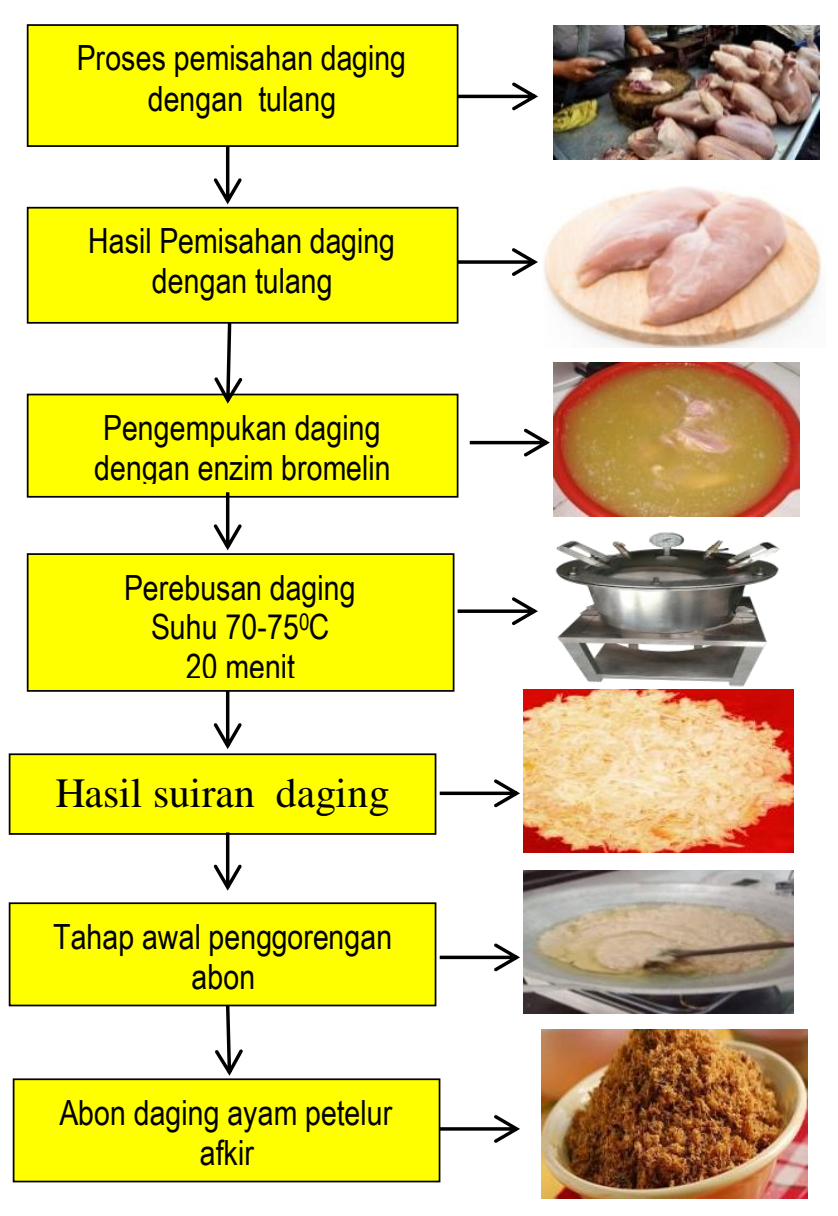

Gambar 1. Diagram alir pembuatan abon daging ayam petelur afkir

\section{Hasil dan Pembahasan}

3.1. Kegiatan pelatihan pembuatan abon daging ayam petelur afkir

Dalam upaya untuk meningkatkan pengetahuan dan keterampilan ibu-ibu anggota PKK "MAVILA" Desa Bajur Kecamatan Labuapi Kabupaten Lombok Barat telah dilakukan pelatihan pembuatan abon berbasis daging ayam petelur afkir yang dilaksanakan pada 17 September 2020. Materi penyuluhan yang disampaikan oleh tim pengabdian terlihat pada Tabel 1.
Tabel 1.Materi Pelatihan Pembuatan Abon Daging Ayam Petelur Afkir

\begin{tabular}{|c|c|c|}
\hline No. & Materi Pelatihan & $\begin{array}{l}\text { Durasi } \\
\text { waktu }\end{array}$ \\
\hline 1. & $\begin{array}{l}\text { Bahan-bahan dan tahapan } \\
\text { dalam pembuatan abon } \\
\text { daging ayam petelur afkir } \\
\text { Praktek pembuatan abon } \\
\text { daging ayam petelur afkir } \\
\text { dan teknik pengemasannya }\end{array}$ & $\begin{array}{l}30 \text { menit } \\
90 \text { menit }\end{array}$ \\
\hline
\end{tabular}

Dalam kegiatan pelatihan tersebut dihadiri oleh 17 orang, 2 diantaranya adalah Kadus dan Ketua RT Desa Bajur. Tingkat persentase kehadiran peserta adalah $85 \%$, karena jumlah peserta yang diundang 20 orang dan yang hadir juga sebanyak 17 orang. Peserta pelatihan terlihat sangat serius mendengar dan memperhatikan materi yang disampaikan oleh nara sumber. Hal ini terlihat bahwa pada waktu diskusi terdapat 3 orang yang bertanya terkait materi yang disampaikan. Dalam pelaksanaan pelatihan tersebut dihadiri oleh Bapak Kepala Dusun dan Bapak Ketua RT Desa Bajur. Kehadiran unsur pemerintah desa ini menjadi salah satu motivator untuk lebih meningkatkan semangat ibu-ibu anggota PKK untuk membuka usaha baru yaitu pembuatan abon. Adapun suasana pelatihan terlihat pada Gambar 2.

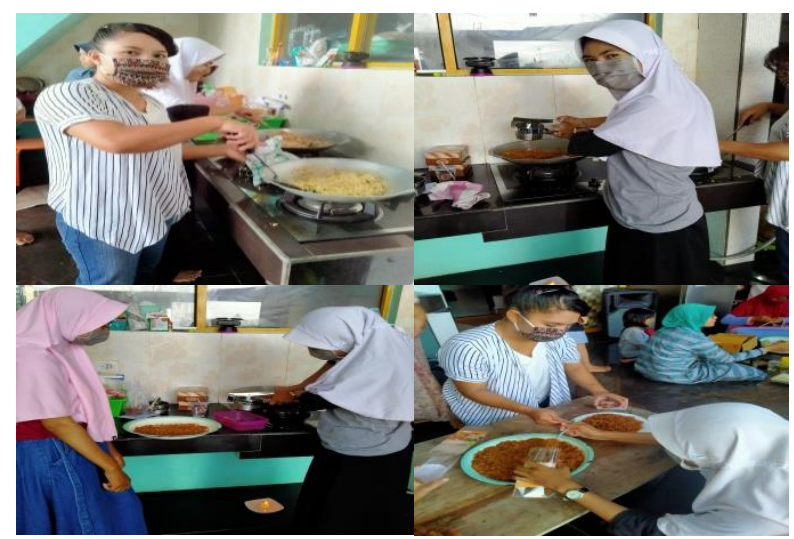

Gambar 2. Suasana pelatihan pembuatan abon berbasis daging ayam petelur afkir 
Dalam pelatihan pembuatan abon telah diterapkan formula pembuatan abon untuk menghasilkan abon sesuai standar SNI seperti terlihat pada Tabel 2 .

Tabel 2. Formula Pembuatan Abon Ayam Petelur Afkir Dalam 1000 gram

\begin{tabular}{lcl}
\hline \multicolumn{1}{c}{ Nama Bahan } & Jumlah Bahan & Satuan \\
\hline Daging & 1000 & Gram \\
Santan & 725 & ml \\
Air Kaldu & 5 & liter \\
Minyak goreng & 250 & ml \\
Lengkuas & 5 & gram \\
Laos & 50 & gram \\
Ketumbar & 5 & sendok \\
Daun salam & 5 & lembar \\
Bawang merah & 125 & gram \\
Bawang putih & 75 & gram \\
Gula pasir & 50 & gram \\
Penyedap & 10 & gram \\
Garam & 50 & gram \\
& & \\
\hline
\end{tabular}

3.2. Bentuk kemasan dan kandungan nilai gizi abon daging ayam petelur afkir.

Bentuk kemasan dari abon daging ayam petelur afkir telah didesain sedemikian rupa sehingga bisa menarik konsumen. Ukuran kemasan yang dibuat bervariasi yaitu mulai dari ukuran 250 gram, 500 gram, 750 gram dan paling besar berukuran 1000 grm. Dalam kemasan dicantunkan beberapa informasi antara lain: Merk abon yang dihasilkan, kandungan nutrisi abon dan bahan-bahan pembuatan abon. Adapun bentuk kemasan yang dihasilkan terlihat pada Gambar 3.

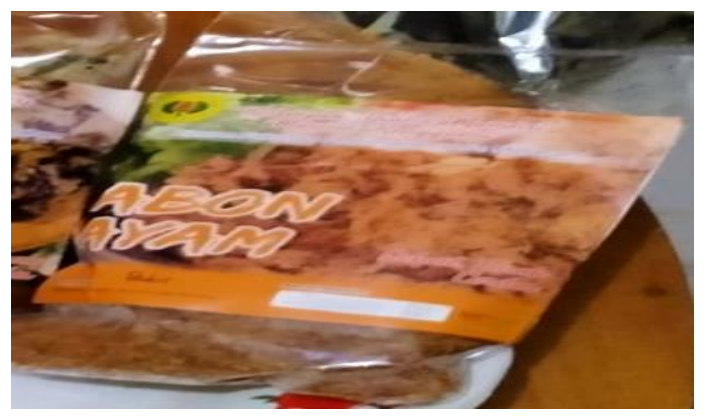

Gambar 3. Bentuk Kemasana Abon Berbasis Daging Ayam Petelur Afkir
Hasil uji laboratorium Ilmu Nutrisi dan Makanan Ternak (INMT) Fakultas Peternakan Universitas Mataram diperoleh bahwa abon daging ayam petelur afkir mempunyai nilai gizi yaitu kadar air 14,33\%, kadar protein 20,34\%, kadar lemak 28,98\%, kadar abu 5,17\% dan protein terlarut $0,11 \%$. Standar SNI:kadar air sebesar $7 \%$, kadar protein 15\%, kadar lemak 30\%, dan kadar abu 7\%. Berdasarkan hasil analisa laboratororium menunjukkan bahwa nilai gizi abon yang dibuat oleh Ibu-ibu anggota PKK "Mavila" telah memenuhi SNI.

\section{Kesimpulan}

1. Kegiatan pengabdian kepada masyarakat ini dapat meningkatkan keterampilan Ibuibu anggota PKK "MAVILA" Desa Bajur Kecamatan Labuapi Kabupaten Lombok Barat serta dapat menumbuhkan semangat untuk membuka usaha dibidang pembuatan abon berbasis daging ayam petelur afkir.

2. Nilai gizi abon daging ayam petelur yang dihasilkan dalam kegiatan pengabdian ini telah memenuhi standar yang ditetapkan oleh SNI.

\section{Daftar Pustaka}

Bulkaini,Hosin, Burhan dan A.Multazam., 2017. Pengaruh Penambahan Berbagai Bahan Pangan Fungsional Terhadap Kualitas Fisik Dan Kimia Abon Yang Berbasis Daging Sapi Kualitas Rendah. Laporan Penelitian Program Vokasi UNRAM Kampus Bima.

Bulkaini. 2018. Wawancara Langsung dengan Pelaku Hom Industri Pembuatan Abon se Kota Mataram.

Bulkaini, Dj.Kisworo, B.R.D. Wulandari, Sukirno dan Wahid Yulianto. 2019. Aktivitas Antioksidan, Sifat Fisik dan Kimia Abon Daging Ayam Petelur Afkir Dengan Perendaman Larutan Kulit Nanas. Laporan Penelitian. 
Bulkaini et al, Jurnal Pengabdian Magister Pendidikan IPA, 2020, 3 (2): 189-194

Fakultas Peternakan Universitas

Mataram.

Soeparno, 2011. Dasar Teknologi Hasil

Ternak. Gajah mada University press. Yogyakarta

Yuwanta. T, 2004. Ilmu Ternak Unggas. Kanisius. Yogyakarta.

Mountney dan Parkhust, 1995. Poultry

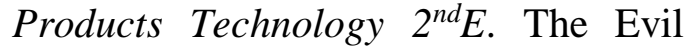
Publishing Co.,Inc. Westpas. 